\title{
Factors Influencing The Implementation Of Government Electronic Procurement System In The County Government Of Nyamira, Kenya
}

\author{
Abuga Renson Nyaporo ${ }^{1}$, DR. Wallace Atambo ${ }^{2}$ \\ ${ }^{1}$ Jomo Kenyatta University of Agriculture and Technology \\ Department of Procurement and Logistics, Nairobi, Kenya \\ ${ }^{2}$ Jomo Kenyatta University of Agriculture and Technology, Kenya
}

\begin{abstract}
The main objective of the study was to examine the factors influencing the implementation of government electronic procurement system in the county government of Nyamira. The specific objectives of this study were: to analyze the influence of e-procurement readiness on implementation of government electronic procurement system; to evaluate the influence of perceived usefulness on implementation of government electronic procurement system and to explore the influence of resistancelacceptance on implementation of government electronic procurement system in the county government of Nyamira. The study adopted a descriptive research design. The target population for the study was the 44 procurement staff in the 11 divisions/ministries in the county government of Nyamira since they are all procurement entities. Primary data were collected using a questionnaire that was pretested to enhance validity and reliability. Descriptive statistics were used in this study aided by Tables, pie charts and graphs were used to present the analyzed results. The study findings indicated that e- procurement readiness aspects among employees of different departments in Nyamira County Government through ICT infrastructure. The findings indicated that user training aspects in Nyamira County Government influenced the effective implementation of the government e-procurement system which improved the user's competencies and skills to embrace electronic procurement. From the research the study recommended the following: The recommends that in the influence of user readiness on the implementation of government electronic procurement, the top management in different departments at Nyamira County Government should allocate enough resources for easy preparation on enhancing e-procurement to improve on its procurement performance. On the effect of user training on implementation of Government electronic procurement system, Nyamira County Government should employ latest technological systems training to staff in doing their procurement activities so as they have their image to the public and society e.g. reducing delivery time through market research/survey before incorporating e-procurement so as they may know what the customers need/require and at what time in which quantity and quality
\end{abstract}

Keywords: Training, E-Procurement , Kenya

\section{Introduction}

Governments have been noted to be the single largest purchaser of a national economy (PPOA, 2009). The importance of public procurement in terms of size relative to World GDP and World trade was enlightened in a report by OECD (2001). The report estimated the value of government procurement market at over 2,000 billion in 1998. This was equivalent to $7 \%$ of the Worlds GDP and 30\% of the world merchandise trade. In a related study, Trionfetti (2000) estimated that the size of public procurement varied between 5 and $8 \%$ of GDP in industrialized countries. Traditionally government procurement has been characterized by manual, paper based activities mainly in defining suppliers or vendors of materials or services purchased by an organization. However, as noted by Kiarie (2011) this has often resulted in inefficiencies, low transparency and low service quality as well as weak oversight roles, delays, poor linkages between procurement and expenditures, and poor record management.

Electronic Government Procurement (E-GP) is the application of technology (particularly online technology) to public sector procurement of goods, works, and services, under an efficient, high-quality management framework and involves harnessing information and communication technology to transform relationships with citizens and businesses and between the arms of the government (Bhatnagar, 2002). Eprocurement systems have proven themselves within various government organizations as an effective tool for instituting procurement reforms and establishing a fully transparent and open procurement environment. As noted in the Expert Group Meeting Report (2011) the business case for implementing an e-procurement system include the following: First, e-procurement enables significant improvement in transparency. This is made possible through traceability of all transactions on an online platform. This in essence provides an audit trail which is essential for the effective prevention of fraud and corruption. Secondly, electronic procurement enables 
enhanced value-for-money. This is made possible by enhancing competition through improved accessibility; reducing procurement costs and transaction costs; facilitating online catalogue based purchases, such as framework contracts; improved market intelligence and resource allocation management. Thirdly, electronic procurement improves work efficiency by reducing disputes; enabling better enforcement of regulations; reducing procurement time; standardization and streamlining of the procurement process.

Studies also show that e-procurement systems have a potential to enable governments to monitor the efficiency and effectiveness of procurement and provide more transparency and accountability. However, such systems are only effective when linked to e-governance information systems as seen in Italy, Scotland and more recently in Western Australia (Coulthard\&Castleman, 2001). Scholars (Segal \& Taylor, 2001; Coulthard\&Castleman, 2001; Basheka, 2008) also contend that e-procurement information system development and implementation is done differently depending on the government and the level of Information Technology (IT) appreciation among the public especially the providers of government. These case studies of e procurement provide information about the potential benefits, impact and consequences of e-procurement information systems.

Korea is seen as a leader with the implementation of a fully integrated e-procurement solution that is integrated with all other electronic government operations, including financial management systems, company registrations and tax systems (Kalakota, 2000). The implementation of the Korean KONEPS system was just one of eleven electronic government system initiatives across various institutions to support a fully integrated environment, including system support for the distribution and management of digital certificates to ensure the authenticity and security of the system and associated processes. Korea invested millions of dollars over a number of years as its system evolved from an electronic tendering system to improve transparency in the procurement process to today's fully integrated e-procurement solution that takes full advantage of the efficiencies an electronic system offers. Though the investment in electronic procurement numbered in the millions and Korea continues to fund millions each year to support system operation and business development activities, the results of the system outweigh the investment with an estimated \$6 billion USD economic impact in savings to government and participating suppliers. KONEPS currently supports over 41,000 public entities, 191,000 registered suppliers and over $\$ 50$ billion in annual procurement activity.

Existing literature reveal that a number of organizations in Kenya have successfully adopted the use of e-procurement technology. Gitahi (2011) cited the example of Nation Media Group which through their digital platform commonly known as N-Soko has enabled their clients to purchase products online. There is also emerging evidence of the slow uptake of the technology despite the benefits that e-procurement offers (Segal \& Taylor, 2001).In the public sector, several models have been tried by different countries to implement eprocurement. These are seller centric buyer centric, e-marketplaces or third-party managed models. In some countries these models are summarized into three: public, the mixed model and public private partnerships. As Meso (2010) noted, the Kenya government has adopted the public model.

The Public Financial Reform Management (PFMR) Strategy Paper 2001-2006 recommended automation as well as integration of key government functions such as human resources payroll, accounting, procurement and budgeting citing transparency, better financial management and reporting as some of the benefits (GoK, 2001). According to E-government Strategy Paper 2004 e-procurement was one of the medium term objectives which were supposed to be implemented by June 2007, but the implementation process was observed to be very slow (GoK, 2004). The National Treasury is a Ministry in Government which is spearheading public financial management reforms. Within the ministry, there is a Department called the Integrated Financial Management Information System (EPS) Department which has the mandate of designing, spearheading and managing the Integrated Financial Management Information System re-engineering process. Through this department, the Integrated Financial Management Information System (EPS) was developed in 1998 and the deployment of the system to ministries started in 2003. The deployment to the counties started in 2012 and as at 2013, only nineteen out of forty seven counties had started using the EPS system. At present the intended users of the EPS system at the counties are being trained on the same from time to time. The Strategic Plan for GoK EPS (2011- 2015) outlined the development of the Integrated Financial Management System (EPS). At present the system is being re-engineered with the aim of improving systems for management and reporting of financial data and information for the Government of Kenya.

\section{Statement of the Problem}

Having two levels of government (the National and the County governments) and with the constitutional requirement dictating the disbursement of at least fifteen per cent of the revenue raised nationally to the forty seven counties, a proper functioning public procurement system is both crucial and important in the Kenyan case. In the 2013/2014 financial year a total of 210 billion Kenya shilling was disbursed to the counties (CRA, 2013). The allocation to county governments has been increasing in the subsequent financial years with a total of 229 billion Kenya shillings disbursed to the counties in the 2014/2015 financial year and 253 billion 
Kenya shillings in the 2015/2016 financial year. In order to integrate key functions such as procurement and accounting; streamline and enhance transparency in management of public funds as well as to provide a framework for standardized reporting, the government adopted the policy requiring all government procuring entities to use the Integrated Financial Management Information System (EPS). The Kenyan electronic government procurement (known as 'Procure to Pay') is anchored in the EPS system.

However, only nineteen out of the forty seven counties had adopted the EPS System as at July 2013. Nyamira County was one of the counties that had not implemented the EPS system as at July 2013 (PPOA Interim Report, 2013). Moreover, the history of implementation of the EPS system since its introduction in Kenya in the year 2003 is riddled with a number of challenges which cannot be ignored globally and regionally. Despite the Government's sustained and incremental efforts in laying down ICT strategies in the area of Public Financial Management Reforms in order to boost transparency, efficiency and effectiveness, it is still apparent that the implementation of e-procurement is still very slow.Findings show that most of the procurement processes in public institutions are still manual with the internet only being used for e-mails and web browsing (PPOA, 2013).This slow implementation of e-procurement in the public sector raises concern as to what factors influence the implementation of e-procurement in the Kenyan public sector particularly in county governments.There have been studies on factors affecting the adoption and implementation of e-procurement in organizations around the world but only a few have sought to address the Kenyan case especially with the new devolved governance structure. Therefore in light of this, this study will seek to examine the factors influencing the implementation of the government electronic procurement system in the county government of Nyamira.

\section{General Objective}

The main objective of the study was to examine the factors influencing the implementation of government electronic procurement system in the county government of Nyamira.

\section{Specific Objectives}

i. To establish the influence of e-procurement readiness on the implementation of government electronic procurement system in the county government of Nyamira.

ii. To examine how user training influences the implementation of government electronic procurement system in the county government of Nyamira.

\section{Literature Review}

The following theories and models constitute the theoretical framework on which this research study is built on. Technology -Organisation-Environment Model (TOE)

Several models have been used within past research studies to explain IT adoption/diffusion. Notable among them are theories such as Davis's Technology acceptance model (TAM), Roger's Diffusion of Innovation (DOI), Fishbein and Ajzen's Theory of Reasoned action (TRA), Ajzen's Theory of Planned Behavior (TPB) and Tornatzky and Fleischer's Technology-organization-environment (TOE) framework. Technology-organizationenvironment framework states that a firm's technology adoption/implementation decisions are influenced by three factors: technology, organization and environment. Technology describes the existing and new technologies relevant to the firm, Organizational factors refer to the available resources within the firm and Environmental describes the industry features where a firm is conducting business (Tornatzky \& Fleischer, 1990).

The TOE framework was developed in 1990 (Tornatzky \& Fleischer 1990). It identifies three aspects of an enterprise's context that influence the process by which it adopts and implements a technological innovation: technological context, organizational context, and environmental context. Technological context describes both the internal and external technologies relevant to the firm. This includes current practices and equipment internal to the firm (Starbuck 1976), as well as the set of available technologies external to the firm (Thompson 1967, Khandwalla 1970, Hage 1980). Organizational context refers to descriptive measures about the organization such as scope, size, and managerial structure. Environmental context is the arena in which a firm conducts its business - its industry, competitors, and dealings with the government (Tornatzky \& Fleischer, 1990).

The TOE framework has been used and empirically validated in several studies with diverse technology innovations and various contexts to explain technology adoption/diffusion decisions (Iacovou, Benbasat et al., 1995; Chau \& Tam, 1997; Kuan \& Chau, 2001; Teo \& Pan, 2004; Zhu \& Kraemer, 2005; Srivastava \&Teo, 2006; Zhu, Dong et al., 2006; Chang, Hwang et al., 2007; Huy, 2007). Based on TOE's solid theoretical foundation and the consistent empirical support presented in earlier research studies, the TOE framework is considered suitable and a good starting point for this study.

TOE framework underscores Rogers' (1995) three groups of adoption predicators- leader characteristics relating to change; internal characteristics (centralization, complexity, formalization, 
interconnectedness, organizational slack and size), and external characteristics (system's openness). The major snag of T-O-E is that some of the constructs in the adoption predictors are assumed to apply more to large organizations, where clients are sure of continuity and less complaints, than to small organizations. However, integrating T-O-E with other models such as TAM, with each adoption predictor offering larger number of constructs than the original provides richer theoretical lenses to the understanding of adoption behavior.

TOE framework is designed for analyzing technology adoption within firms in various contexts. Businesses in developed and developing countries are significantly different. Organizations in developed countries have access to more resources and face more competition than organization in developing countries (Dasgupta, Agarwal et al., 1999). Against this background and after review of other technology adoption models, TOE appears most suitable to ground this study. A review of existing literature shows limited evidence of the TOE framework having been applied to technology diffusion within an African context and Kenya in particular.

\section{Technology Acceptance Model}

Davis (1993) developed and validated the Technology Acceptance Model (TAM) to explain the mechanisms that influence and shape users' acceptance of new information technology. According to TAM, there are two specific variables that are fundamental determinants of users' attitude toward using information technology and actual use of the system: perceived usefulness and perceived ease of use relatively to new information system design features.Before e-procurement adoption, administrators have to assess employees' attitude across to this new information technology, in order to prevent a failure in implementation and waste of resources. Administrators have to provide safe and high quality services under the pressure of limited resources. Computers, information systems and technologies have penetrated to public organizations and enhanced their performance by providing better communication, access to information and knowledge and promoting innovation and efficiency (Dewett \& Jones, 2001).

A well designed process and policy willing can be essential pre-conditions for e-procurement implementation. However, there is a crucial variable which put at risk the success of the implementation. Abolition of the traditional handwritten procedure and its replacement of new procedures based on the use of computer and information technology consist some of the major changes. Resistance to change is a barrier for eprocurement process construction and users' acceptance isn't considered given (Rahim, 2008).

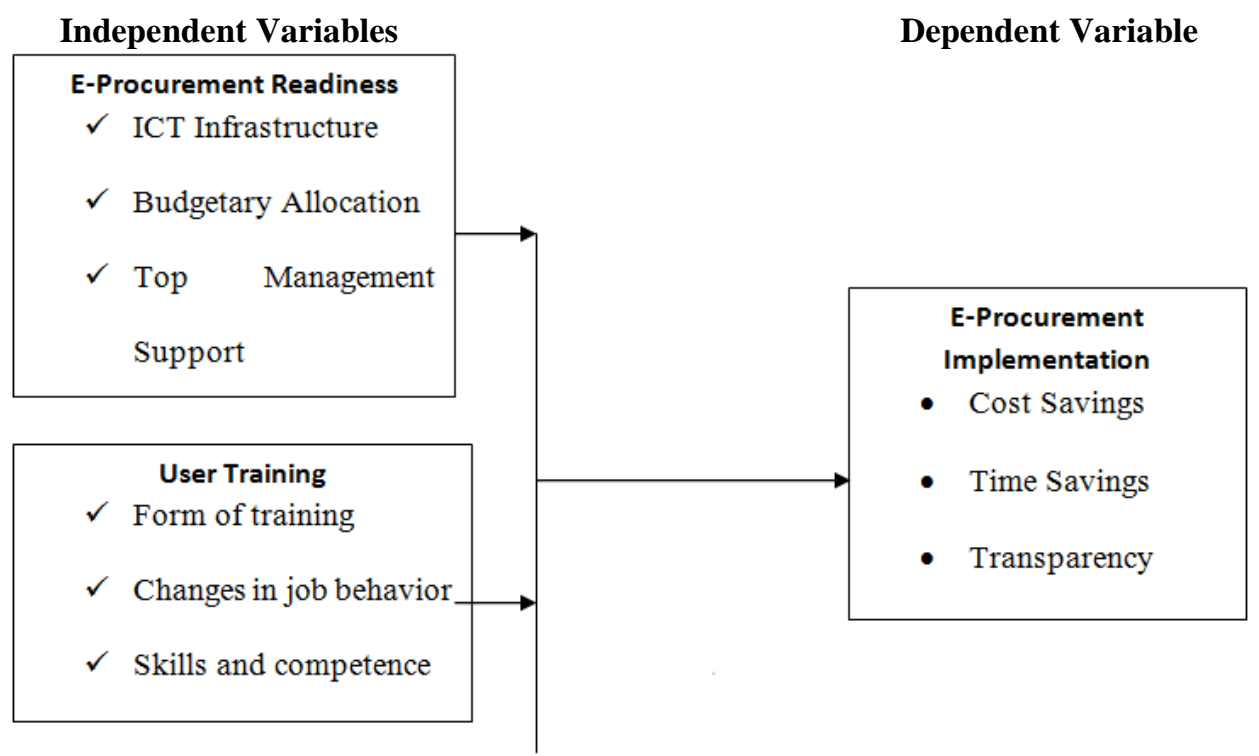

Figure 1 Conceptual Framework

\section{Empirical Review of Literature}

\section{E-procurement Readiness and E-procurement Implementation}

Orina (2013) in her study on E-procurement readiness factors in Kenya's Public sector found that resistance to change, lack of enthusiasm, staff skills, and to some extent procurement policies impacted the readiness of e-procurement in public institutions. According to her findings, the main e-procurement readiness factors include: technology, organization's finance, leadership and integrity, legal framework and technical preparedness, international law and employee attitude, procurement policy and national procurement law, eprocurement adoption and staff I.T adequacy, and online marketplace and government support. 
Technological resources have been consistently identified as an important factor for successful information systems adoption. Technologies have changed and redefined the way organizations and government corporations operate. Organizations adopt new technologies to improve the efficiency and effectiveness of various work processes. Unfortunately, many technology-based products and services never reach their full potential, and some are simply rejected (Burton-Jones \& Hubona, 2006). Failed investments in technology may not only cause financial losses, but also lead to dissatisfaction among employees (Venkatesh, 2000). Hence, explaining and predicting user adoption of new technology is important. New technology adoption by service employees is affected by various factors. Some of them include; technology readiness, technology integration and interoperability with the existing IT systems and the IT security applications. Research by Parasuraman and Colby (2009) pointed that technology readiness (TR) is a key factor in the adoption of innovative products and services. TR refers to the propensity to adopt and embrace technology in home life or work. It reflects a set of beliefs about technology and is not an indicator of competence. TR is highly predictive of the speed of technology adoption and level of usage of technology in consumer households and organizations. TR is multifaceted, with some factors being contributors and some factors behind inhibitors.

According to Mose, Njihia \& Magutu (2013) private and public sector organizations have been utilizing information technology (IT) systems to streamline and automate their purchasing and other processes over the past years. Chaffey (2009) states there have been many attempts to automate the process of procurement for the buyer using electronic procurement systems (EPS), workflow systems and links with suppliers through electronic data interchange (EDI). Further, not all the technology is in place yet to enable the Government to take full advantage of internet commerce (PPOA, 2009). The PPOA in 2009 identified issues in identification of parties in a transaction, synchronization, confidentiality, data integrity and bandwidth as the major considerations that the government had to make before taking full advantage of the benefits of eprocurement.

Sigala (2003) indicates that e-purchasing adoption can be influenced by a large firm size and purchasing workforce. The rationale is that a buying firm with a larger purchasing unit is more likely to adopt epurchasing, as it has greater information processing capacity, needs and organizational power than smaller firms. Moreover, a buying firm with a large purchasing unit is also more likely to possess the financial, skill resources and bargaining power to achieve the economies of scale required.

The results of quantitative research by Chatterjee et al. (2006) prove that top management championship positively influences extent of organizational assimilation of web technologies in e-commerce strategies and activities. Managerial productivity and strategic decision aids are defined in the article of Grandon and Pearson (2004) as important factors in e-commerce adoption in organizations. Managerial productivity refers to managers' perception that e-commerce provides better access to information, helps in the management of time, improves communication among managers. Top management can stimulate change by communicating and reinforcing values through an articulated vision for the organization. Top management support is critical for creating a supportive climate for the adoption of new technologies. Top management support, organizational adaptation, and training of employees are examples of issues for the successful implementation of organization IT system (Kawalek, 2003). Jeyaraj (2006) found that top management support to be one of the best predictors of organization adoption of Information System innovations.

According to World Bank (2013) the cost of purchasing e-procurement software can be huge and may be prohibitively expensive for smaller organizations. They must consider not only the price of the software itself but other costs associated with the system and its implementation. Those additional costs include networking infrastructure, information technology hardware and software, application design, development and implementation, training, and maintenance of equipment. There is also the time required for employees to learn the new system.

\section{User Training and E-procurement Implementation}

E-Procurement applications focus on creating efficiencies with the goal being to make the traditional purchasing procedures more efficient and cost effective ( $\mathrm{Wu}, 2007)$. The development and implementation of electronic commerce business models such as a procurement portal in organizations is a challenge that goes beyond mere technological functionality (Turban et al, 2006). Adopting of a new technology needs skill and knowledge to operate in the organizations and most organizations do not implement because organizations' employees are not familiar with new technology. Empirical evidence identifies that organization whose employees have the necessary skills and technical knowledge are more likely to implement e-Government applications (Lin \& Lee, 2005).

Armstrong (2000) points out that training is the formal and systematic modification of behavior through learning which occurs as result of education instruction development and planned experience. The fundamental aim of training is to help the organization achieve its purpose by adding value to its key resources the people it employs. Training means investing in people to enable them to make the best use of their natural 
abilities. The objectives of training are to develop the skills and competence of employees and improve their performance, help people to grow within the organization in order that as far as possible in new job as appointment transfer or promote and ensure that they become fully competent as quickly and economically as possible. Effective training can minimize learning costs, improve individual, terms and co-operate performance in terms of output, quality speed and overall productivity. To improve operational flexibility by extending the shape of skills possessed by employees (multi-skilling) increases the commitment of employees by encouraging them to identify with the mission and objectives of the organization and to provide high level of services to customer.

Due to the increase of technological advancement, constant training on the skills to handle all kinds of problems in communication to achieve effective communication is essential. For example until recently office switchboard operator all the individual telephone was received and make calls controlled telephone system. But recent microelectronics has been introduced and so increased commercial competition. And so employees have to train to achieve the goal of organization. Training of staff plays quite an important role in the organization. It comprises of monitoring and planning, welcoming change and equipping people to adapt in any organization. Training ensures that an organization has people with the correct mix of attributes which is achieved by the provision of appropriate learning opportunities and enabling them to reform the highest levels of quality and service (Bentley, 1994).

\section{Research Design}

\section{Research Methodology}

The study adopted a descriptive research design given the objectives and as illustrated in chapter two under conceptual framework. According to Cooper and Schindler, (2006) descriptive research design enables the researcher to narrate how various behaviors and events occur. This design was appropriate because on one hand, graphical illustrations were used to describe various variables of interest. On the other hand, the design was used to establish the magnitude, direction and significance of various implementation factors on implementation of the government electronic procurement system in Nyamira County

\section{Target Population}

The study population were all the departments of Nyamira County which are procurement entities and the target population were all the procurement staff in the various departments of Nyamira County. According to Nyamira County (2016), there are 11 departments in the County Government of Nyamira with each department having a procurement unit. The study population of this study comprised of all the Procurement staff in each of these 11 departments in the County Government of Nyamira comprising of a total of 44 respondents. The number of procurement staff under each department is presented in table 1.

Table 1: Distribution of the Target Population

\begin{tabular}{|l|l|}
\hline Department/Ministry & Number of Procurement Staff \\
\hline Agriculture, Livestock \& Fisheries & 4 \\
\hline Education & 4 \\
\hline Finance \& Economic Planning & 4 \\
\hline Health & 4 \\
\hline Planning, Land \& Housing & 4 \\
\hline Tourism & 4 \\
\hline Trade, Energy and Industry & 4 \\
\hline Transport \& Infrastructure & 4 \\
\hline Water \& Environment & 4 \\
\hline Youth, Gender and Sports & 4 \\
\hline Inspectorate & 4 \\
\hline Total & $\mathbf{4 4}$ \\
\hline
\end{tabular}

Source :Nyamira County Public Service Board ,2015

\section{Sampling procedure and sample size}

Saunders et al., (2007) refers to sample as a subset of the target population. A sample can be used to derive inferences about the population if appropriate sample size and sampling techniques are used. A sample size is the number of units of observation that the researcher intends to collect information from. In our case, it is the number of procurement staff in the 11 departments of Nyamira County that the researcher intended to collect data on factors influencing the implementation of the government electronic procurement system. Due to the small population size, the study adopted a census approach. 


\section{Data collection procedure}

Data collection involved a self-administered questionnaire. The researcher dropped the questionnaires personally at the respondent's place of work. The questionnaires were then collected after a period of two weeks. 44 questionnaires were distributed to the Procurement staff in the 11 departments of Nyamira County Government to fill in. After two weeks, duly filled questionnaires were collected for further processing of data at the end of the data collection period that was expected to last up to three weeks.

\section{Data Analysis and Presentation}

This study is expected to produce both quantitative and qualitative data to explain the factors influencing the implementation of government electronic procurement system exhaustively. Once the questionnaires are received they were coded and edited for completeness and consistency. Quantitative data were analyzed by employing descriptive statistics and inferential analysis using statistical package for social science (SPSS). The positive (H1) hypothesis testing was done at 5\% level of significance. The data were then presented using frequency distribution tables, bar charts and pie charts for easier understanding.

\section{Results And Discussion}

Descriptive statistics was used to discuss the findings of the study. The study targeted 44 respondents from which 37 respondents filled and retuned the questionnaires making a response rate of $84 \%$.This response rate was satisfactory to make conclusions for the study as Cooper and Schneider (2003), states that a response rate of between 30 to $80 \%$ of the total sample size can be used to represent the opinion of the entire population.

\section{Adoption of Government Electronic Procurement Module}

Table 4.5 E- Procurement Practices-Level of Adoption

(Key: SA-strongly agree, A-agree, UD-undecided, D-disagree, SD-strongly disagree)

$\begin{array}{lllllllll}\text { E- Procurement Practices-Level of } & \text { SA } & \text { A } & \text { UD } & \text { D } & \text { SD } & \square \text { fi } & \square \text { fiwi } & \square \text { fiwi } \\ \text { Adoption } & 5 & 4 & 3 & 2 & 1 & & \end{array}$

$\begin{aligned} & \text { e-Requisitioning (sending requests of } \\ & \text { requirements to the AIE holders for } \\ & \text { approval) }\end{aligned}$
$\begin{aligned} & \text { e-Tendering- (sending requests for } \\ & \text { information and prices to suppliers } \\ & \text { and receiving the responses of } \\ & \text { suppliers using Internet technology) }\end{aligned}$
$\begin{aligned} & \text { e-Catalogue- (list of goods or } \\ & \text { services on sale with their description } \\ & \text { and prices published as an electronic } \\ & \text { document) }\end{aligned}$

Table 2 indicates that rating 4.16 of the respondents said that e-Requisitioning (sending requests of requirements to the AIE holders for approval) was the level at which electronic procurement practices had been adopted in Nyamira County Government. Rating 3.86 of the total respondents said that e-Tendering- (sending requests for information and prices to suppliers and receiving the responses of suppliers using Internet technology) was the level at which electronic procurement practices had been adopted in Nyamira County Government. Rating 3.95 of the respondents said that e-Catalogue- (list of goods or services on sale with their

DOI: $10.9790 / 487 X-1903026979 \quad$ www.iosrjournals.org $\quad 75 \mid$ Page


description and prices published as an electronic document) was the level at which electronic procurement practices had been adopted in Nyamira County Government. Rating 4.11 of the total respondents said that eInvoicing- (delivery of bills and related information using electronic communications) was the level at which electronic procurement practices had been adopted in Nyamira County Government. Rating 4.0 of the total respondents said that e-Auction- (sell or bid for products or services via the Internet). Rating 3.89 of the total respondents said that e-Sourcing- (identifying new suppliers using Internet technology was the level at which electronic procurement practices had been adopted in Nyamira County Government. Rating 4.0 of the total respondents said that e-Informing- (gathering and distributing purchasing information) both from and to internal and external parties using Internet technology) was the level at which electronic procurement practices had been adopted in Nyamira County Government.

\title{
Effects of User Training Aspects on implementation of Electronic Procurement
}

The study sought to establish from the respondents on the effects of user training in enhancing implementation of government electronic procurement system in Nyamira County Government. The response rate from the field were record in Table 3.

Table 3 Effects of User Training Aspects on implementation of Electronic Procurement (Key: SA-strongly agree, A-agree, UD-undecided, D-disagree, SD-strongly disagree)

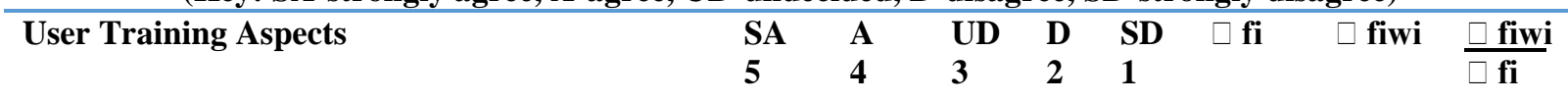

\begin{abstract}
User training influences the effective
implementation of the government e-procurement system in Nyamira County
\end{abstract} 20 11

23

37

$158 \quad 4.24$

The users of e-procurement are well trained and 14

10

47

37

138

3.73 able to use the system well in my department

\begin{tabular}{|c|c|c|c|c|c|c|c|c|}
\hline $\begin{array}{l}\text { The County Government of Nyamira conducts } \\
\text { regular training to all e-procurement system users } \\
\text { that focuses on improving the users competencies } \\
\text { and skills to embrace electronic procurement. }\end{array}$ & 18 & 10 & 3 & 3 & 3 & 37 & 148 & 4.0 \\
\hline $\begin{array}{l}\text { The e-procurement training in Nyamira county } \\
\text { ensures that there is sufficient in-house competent } \\
\text { and skilled human capital to implement e } \\
\text { procurement }\end{array}$ & 15 & 11 & 4 & 5 & 2 & 37 & 143 & 3.86 \\
\hline $\begin{array}{l}\text { User training on the government e-procurement } \\
\text { system in Nyamira County has reduced staff } \\
\text { resistance }\end{array}$ & 10 & 13 & 6 & 5 & 3 & 37 & 133 & 3.59 \\
\hline
\end{tabular}

Table 3 indicates that rating 4.24 of the total respondents said that user training influences the effective implementation of the government e-procurement system in Nyamira County was an effect of user training o enhancing implementation of government electronic procurement system in Nyamira County Government. Rating 3.73 of the total respondents said that users of e-procurement are well trained and able to use the system well in my department was an effect of user training o enhancing implementation of government electronic procurement system in Nyamira County Government. Rating 4.0 of the total respondents said that County Government of Nyamira conducts regular training to all e-procurement system users that focuses on improving the users competencies and skills to embrace electronic procurement was an effect of user training o enhancing implementation of government electronic procurement system in Nyamira County Government. Rating 3.86 of the total respondents said that The e-procurement training in Nyamira county ensures that there is sufficient inhouse competent and skilled human capital to implement e procurement was an effect of user training o enhancing implementation of government electronic procurement system in Nyamira County Government. 
Rating 3.59 of the total respondents said that user training on the government e-procurement system in Nyamira County has reduced staff resistance to the system and has made most users to prefer e-procurement over the manual system was an effect of user training o enhancing implementation of government electronic procurement system in Nyamira County Government. Armstrong (2000) points out that training is the formal and systematic modification of behavior through learning which occurs as result of education instruction development and planned experience. The fundamental aim of training is to help the organization achieve its purpose by adding value to its key resources the people it employs. Training means investing in people to enable them to make the best use of their natural abilities. Effective training can minimize learning costs, improve individual, terms and co-operate performance in terms of output, quality speed and overall productivity.

\section{Conclusion And Recommendations}

The study concluded that e-procurement readiness in Nyamira County Government was readily implemented despite the challenges of applying e-procurement like lack of cooperation from top management ineffective computer system, long lead-time and incorrect stock status and lack of supplier cooperation. Eprocurement has experienced a good portion of it with its performance helping Nyamira County Government to the high levels like it has helped managers to reduce inventory control, minimized workforce overtime, high inventory turnover ratio improved consistency of time customer delivery and determine the most economical lot sizes for orders.

In the study it was concluded that user training influenced the effective implementation of the government e-procurement system in Nyamira County through trained staff being able to use the system well. The fundamental aim of training is to help the organization achieve its purpose by adding value to its key resources the people it employs.

\section{Recommendations}

The study recommends that influence of user readiness on the implementation of government electronic procurement, the top management in different departments at Nyamira County Government should allocate enough resources for easy preparation on enhancing e-procurement to improve on its procurement performance. On the effect of user training on implementation of Government electronic procurement system, Nyamira County Government should employ latest technological systems training to staff in doing their procurement activities so as they have their image to the public and society by reducing delivery time.

\section{Suggestions for Further Studies}

From the study, the researcher suggests that further studies should be done on the determinants of eprocurement on performance at Nyamira County Government. Other study should be carried out to establish strategies to be adopted by county governments to enhance procurement effectiveness and further research should be done on effect of staff skill on procurement innovativeness.

\section{References}

[1]. Ajzen, I. (1987). Attitudes, traits, and actions: Dispositional prediction of behavior in personality and social psychology. Advances in experimental social psychology, 20(1), 1-63.

[2]. Ajzen, I. (1991). The theory of planned behavior. Organizational behavior and human decision processes, 50(2), 179-211.

[3]. Aman, A., \&Kasimin, H. (2011). E-procurement implementation: a case of Malaysia government. Transforming Government: People, Process and Policy, 5(4), 330-344.

[4]. Armitage, C.J., \& Conner, M. (2001). Efficacy of the theory of planned behavior: A meta- analytic review. British journal of social psychology, 40(4), 471-499.

[5]. Bartezzaghi, E., \&Ronchi, S. (2004). A portfolio approach in the e-purchasing of materials.Journal of Purchasing and Supply Management, 10(3), 117-126.

[6]. Bashir, M., Afzal, M. T., \&Azeem, M. (2008). Reliability and Validity of Qualitative and Operational Research Paradigm: Pakistan Journal of Qualitative and Operational Research, 4, (1), 35-45.

[7]. Bertot, J. C., Jaeger, P. T., \& Grimes, J. M. (2010).Using ICTs to create a culture of transparency: E-government and social media as openness and anti-corruption tools for societies.Government Information Quarterly, 27(3), 264-271.

[8]. Best, J.W., \& Kahn, J.V. (2006).Research in Education $\left(10^{\text {th }}\right.$ Ed.): New York: Pearson Education Inc.

[9]. Birks, C., Bond, S., \& Radford, M. (2001). Guide to e-Procurement in the Public Sector: Cutting through the Hype. London: Office of Government Commerce.

[10]. Bozarth, C., Handfield, R. and Das, A. (2008). Stages of global sourcing strategy evolution: an exploratory study. Journal of Operations Management, vol. 16, iss 2-3, pp. 241-255.

[11]. Chan, C., \&Swatman, P. M. (1998). EDI implementation: a broader perspective. In Bled "98"- 11 $1^{\text {th }}$ International Conference on Electronic Commerce (pp. 8-10).

[12]. Chen, C.D., Fan, Y.W., \&Farn, C.K. (2007).Predicting electronic toll collection service adoption: An integration of the technology acceptance model and the theory of planned behavior.Transportation Research Part C: Emerging Technologies, 15(5), 300-311.

[13]. Consortium for Global Electronic Commerce (CGEC) (2002).Measuring and Improving Value for E-procurement Initiatives. Madison, WI: University of Wisconsin- Madison, Consortium for Global Electronic Commerce.

[14]. Cooper, R., \& Schindler, P. (2006).Marketing Research.New York: McGraw-Hill.

[15]. Cooper, R.B., \&Zmud, R.W. (1990). Information technology implementation research: a technological diffusion approach. Management science, 36(2), 123-139. 
Factors Influencing The Implementation Of Government Electronic Procurement System In The ..

[16]. Creswell, J. W. (2003). Research Design: Qualitative, Quantitative and Mixed Methods Approaches (2 ${ }^{\text {nd }}$ Ed). London: Sage Publications.

[17]. Croom, S., \& Brandon-Jones, A. (2007). Impact of e-procurement: experiences from implementation in the UK public sector. Journal of Purchasing and Supply Management, 13(4), 294-303.

[18]. Davis, F. D. (1989). Perceived usefulness, perceived ease of use, and user acceptance of information technology.MIS quarterly, 319-340.

[19]. Davies, D., \& Dodd, J. (2002).Qualitative research and the question of rigor: Qualitative Health research, 12(2), 279-289.

[20]. Davila, A., Gupta, M., \& Palmer, R. (2003).Moving Procurement Systems to theInternet: the Adoption and Use of E-Procurement Technology Models.European Management Journal, 21(1), 11-23.

[21]. Davis, F.D., Bagozzi, R.P., \&Warshaw, P.R. (1989). User acceptance of computer technology: a comparison of two theoretical models. Management science, 35(8), 982-1003.

[22]. De Boer, L., Harink, J. and Heijboer, G. (2002).“A conceptual model for assessing the impact of electronic procurement”, European Journal of Purchasing \& Supply Management, Vol. 8, pp. 25-33.

[23]. Doherty, N. F., McConnell, D. J., \& Ellis-Chadwick, F. (2013).Institutional responses to electronic procurement in the public sector.International Journal of Public Sector Management, 26(6), 495-515.

[24]. ECOM Group. (2002). e-Procurement in the UK Public Sector: A Guide to Developments and Best Practices. In A CIPFA $e$ Government Forum Report). London, UK.

[25]. Fishbein, M. (1975).Belief, Attitude, Intention, and Behavior: An Introduction to Theory and Research.

[26]. Gefen, D., Karahanna, E., \& Straub, D.W. (2003). Trust and TAM in online shopping: an integrated model. MIS quarterly, 27(1), 51-90.

[27]. Ginzberg, M. J. (1980). An organizational contingencies view of accounting and information systems implementation.Accounting, Organizations and Society, 5(4), 369-382.

[28]. Greene, H., (2012). Econometric Analysis ( $7^{\text {th }}$ Ed.). Upper Saddle River, N. J: Prentice Hall.

[29]. Hamner, M. and Qazi, R. (2009). "Expanding the technology acceptance model to examine personal computing technology utilization in government agencies in developing countries", Government Information Quarterly, Vol. 26, pp. 128-36.

[30]. Hawking, P., Stein, A., Wyld, D. and Foster, S. (2004). "E-procurement: is the ugly duckling actually a swan down under?",Asia Pacific Journal of Marketing and Logistics, Vol. 16 No. 1, pp. 3-26.

[31]. Hawking, S. (1996).The Nature of Space and Time. New York: Princeton University Press.

[32]. Heijden, H., Verhagen, T. and Creemers, M. (2003)."'Understanding online purchase intentions: contributions from technology and trust perspectives", European Journal of Information Systems, Vol. 12, pp. 41-8.

[33]. IBM Global Services (2003)."Local Government e-Procurement Strategy Report-Management Summary". Retrieved from http://www.lgbcsb.ie/Management-Summary-issued.pdf

[34]. Igbaria, M., Parasuraman, S., \&Baroudi, J. J. (1996).A motivational model of microcomputer usage.Journal of management information systems, 127-143.

[35]. Kassim, E. S., \&Hussin, H. (2010). Public e-procurement: a research synthesis. In e-Education, e-Business, e-Management, and eLearning, 2010.IC4E'10. International Conference on (pp. 150-154). IEEE.

[36]. Kim, T., Lee, J. and Law, R. (2008)."An empirical examination of the acceptance behaviour of hotel front office systems: an extended technology acceptance model", Tourism Management, Vol. 29, pp. 500-13.

[37]. Klein, L. and Ford, G. (2003)."Consumer search for information in the digital age: an empirical study of pre-purchase search for automobiles", Journal of Interactive Marketing, Vol. 13 No. 3, pp. 29-49.

[38]. Kothari, C.R. (2004). Research methodology - Methods and techniques, $2^{\text {nd }}$ Edition New Age Tecno Press, New Delhi.

[39]. KPMG (2001).University of Califonia Office of the President System-Wide E-Procurement Assessment and Strategy Recommendation.Berkely, CA: KPMG Consulting.

[40]. Lederer, A. L., Maupin, D. J., Sena, M. P., \&Zhuang, Y. (2000). The technology acceptance model and the World Wide Web.Decision support systems, 29(3), 269-282.

[41]. Lee, M.C. (2009). Factors influencing the adoption of internet banking: An integration of TAM and TPB with perceived risk and perceived benefit. Electronic Commerce Research and Applications, 8(3), 130-141.

[42]. Lee, J., Ni, J., \&Koc, N. (2001). Draft report NSF workshop on Tether free technology for e-manufacturing, e-maintenance and eservice, organized'. NFS industry/University Co-operation Research Center, 1-2.

[43]. Leipold, K., Klemow, J., Holloway, F., \&Vaidya, K. (2004). The World Bank e-procurement for the selection of consultants: Challenges and lessons learned. Journal of Public Procurement, 4, 319-339.

[44]. Liao, S. H., Cheng, C. H., Liao, W. B., \& Chen, I. (2003).A web-based architecture for implementing electronic procurement in military organizations.Technovation, 23(6), 521-532.

[45]. Lin, B., \& Hsieh, C.T. (2000). Online procurement: implementation and managerial implications. Human Systems Management, 19(2), 105-110.

[46]. Locke, E.A., \& Latham, G.P. (2002).Building a practically useful theory of goal setting and task motivation: A 35-year odyssey. American Psychologist, 57, 705-717.

[47]. Lysons, K., \& Farrington, B. (2006).Purchasing and supply chain management. Pearson Education.

[48]. Makau, J., \&Onyango, J. (2010). Supermarket scramble for Nairobi shoppers Business Daily Africa, page 16.

[49]. Mandrish, E.M. and Schaffer, R.H. (2005)."Results-driven change: a new look at reengineering”, Human Resources Professional, Vol. 8 No. 5, pp. 7-11.

[50]. Mathieson, K., Peacock, E. and Chin, W. (2001).“Extending the technology acceptance model: the influence of perceived user”, The Data Base for Advances in Information Systems, Vol. 32 No. 3, pp. 86-113.

[51]. McKechnie, S., Winklhofer, H. and Ennew, C. (2006). "Applying the technology acceptance model to the online retailing of financial services", International Journal of Retail \& Distribution Management, Vol. 34 Nos 4/5, pp. 388-410.

[52]. McMillan, J. H., \& Schumacher, S. (2006). Research in education: Evidence-Based Inquiry. New York. Pearson Education, Inc.

[53]. Min, H., Smolinski, T.G., \&Boratyn, G.M. (2001).A Genetic Algorithm-based Data Mining Approach to Profiling the Adopters and Non-Adopters of E-Purchasing.In IRI (pp. 1-6).

[54]. Monette, D.R., Sullivan, T.J., \&DeJong, C.R. (2002).Applied Social Research. Orlando, FLA: Harcourt Press.

[55]. Mugenda, O. \&Mugenda, A. (2003).Research Methods: Qualitative and Quantitative Approaches. Nairobi, Acts Press.

[56]. Ngechu M., (2004). Understanding the research process and methods.An introduction to research methods. Acts Press, Nairobi.

[57]. Organisation for Economic Co-operation and Development (OECD). (2008). Fighting Bribery in Public Procurement in AsiaPacific. Retrieved from OECD Public Management Reviews: http://www.oecd.org/publishing 
Factors Influencing The Implementation Of Government Electronic Procurement System In The ..

[58]. OGC (Office of Government Commerce) (2002).A Guide to E-procurement for the Public Sector, Office of Government Commerce, London.Retrieved from www.ogc.gov.uk

[59]. Office of Government Commerce.(2008). A guide to e-procurement for the public sector. Retrieved from OGC Website: http://www.ogc.gov.uk

[60]. Orina, D. (2013). E-procurement readiness factors in Kenya's Public sector. Doctoral dissertation, University of Nairobi.

[61]. Orodho A.J., (2003). Essentials of Educational and Social Science Research methods: Qualitative and Quantitative Approaches. Nairobi, Acts Press.

[62]. Patton, M. Q. (2002). Qualitative evaluation and research methods ( $3^{\text {rd }}$ Ed.). Thousand Oaks, CA: Sage Publications, Inc.

[63]. Pavlou, P.A. (2003). "Consumer acceptance of electronic commerce: integrating trust and riskwith the technology acceptance model", International Journal of Electronic Commerce, Vol. 7 No. 3, pp. 101-34.

[64]. Robson, C. (2002). Real World Research.(2 ${ }^{\text {nd }}$ Ed.) Blackwell.

[65]. Saunders, M., Lewis, P., \&Thornhill, A. (2007).Research Methods for Business Students, (4 ${ }^{\text {th }}$ Ed.).Prentice Hall Financial Times, Harlow.

[66]. Sheng, M.L. (2002). "The impact of Internet-based technologies on the procurement strategy", in Proceedings of the 2nd International Conference on Electronic Commerce, Taipei, December.

[67]. Shim, S., Eastlick, M., Lotz, S. and Warrington, P. (2001) "An online pre-purchase intentions model: the role of intention to search", Journal of Retailing, Vol. 77, pp. 397-416.

[68]. Stratman, J.K. and Roth, A.V. (1999). “Enterprise resource planning competence: a model, propositions and pre-test, design-stage scale development", Proceedings of the $30^{\text {th }}$ Annual Meeting of the Decision Sciences Institute, New Orleans, pp. 1199-201.

[69]. Subramaniam, C., \& Shaw, M. J. (2002). A study of the value and impact of B2B ecommerce: the case of web-based procurement. International Journal of Electronic Commerce, 6, 19-40.

[70]. Tonkin, C. (2003). E-Procurement in the public sector: Story, Myth and Legend. Retrieved from Policy institute: http://www.policyinstitute.tcd.ie/working_papers/PIWPO7\%20\%-20\%Tonkin.pdf

[71]. Vaidya, K., Sajeev, A. S. M., \&Callender, G. (2006). Critical factors that influence e-procurement implementation success in the public sector. Journal of public procurement, $6(1 / 2), 70$.

[72]. Ware, G.T., Moss, S., Campos, J.E., \&Noone, G. P. (2011).Corruption in procurement.Handbook of Global Research and Practice in Corruption, 65.

[73]. Weiss, L. and Thurbon, E. (2006).“The Business of Buying American: Public Procurement as Trade Strategy in the USA,” Review of International Political Economy 13:701-724.

[74]. Wu, I.L., \& Chen, J.L. (2005). An extension of trust and TAM model with TPB in the initial adoption of on-line tax: an empirical study. International Journal of Human-Computer Studies, 62(6), 784-808.

[75]. Yi, M.Y., \& Hwang, Y. (2003).Predicting the use of web-based information systems: self-efficacy, enjoyment, learning goal orientation, and the technology acceptance model.International journal of human-computer studies, 59(4), $431-449$.

[76]. Zima, P.V., (2007). What is theory? Cultural Theory as Discourse and Dialogue. London: Continuum. 